\title{
The Invention of Papal History \\ Onofrio Panvinio between Renaissance and Catholic Reform
}

\author{
Stefan Bauer \\ (Oxford and New York: Oxford University Press, 2020) \\ (Oxford-Warburg Studies) \\ [ISBN 9780198807001] \\ STEFAN SCHÖCH \\ Institut für katholische Theologie \\ Humboldt Universität Berlin
}

Somehow betrayed by this provocative title, the reader would expect that Stefan Bauer's book suggests a new interpretation of papal historiography along the lines of a post-modern revision of its purposes. Nothing could be further from Bauer's intentions. In his view, papal history was invented in the second half of the sixteenth century because only then historians started to reconstruct the Roman past through the skillful use of a large amount of sources and by posing 'hard questions about the reality of change in the Church's past' (15). This change of pace would be the consequence of the so-called Catholic Reform and Counterreformation, two phenomena that, especially in the realm of historiography, appear hard to separate neatly from each other. As a matter of fact, papal historians cautiously navigated between both these poles. On the one hand, they presented themselves as the champions of the Counter-reformation in the most literal sense of the term: their work constituted the Roman riposte to the new Protestant versions of Church history. On the other hand, they were personally involved in the process of internal renewal that the Catholic Church was experiencing. Through their works they no longer aimed to legitimate curial and papal power as it was, but sought to forge a new 'self-perception of the papacy' (2) and hence to propose a different view of the Church. As Bauer keenly points out, modern historians have usually searched for the roots of this new image of the Papacy in the works of art that papal patronage promoted throughout the early modern period. Historical writing shows another facet of this grandiose project. Bauer's book not only shows how history was written in the early modern Rome, but also intends to point out the innovative role that historical writing played in shaping a new representation of the Catholic Church.

Bauer does not formulate clear definitions and avoids methodological and terminological discussions. The introduction offers little more than a summary of the book and some preliminary remarks on the main character of the book, the

Cromohs (Cyber Review of Modern Historiography), ISSN 1123-7023, 23/2020

(C) 2020 The Authors. This is an open access article published by Firenze University Press under the terms of the Creative Commons Attribution Licence, which permits use, distribution and reproduction in any medium, provided the original work is properly cited

DOI: $10.36253 /$ cromohs-12002 
Augustinian friar Onofrio Panvinio (1530-1568). Chapters 1 and 2 provide a detailed biography, with the goal of updating the one published in 1899 by Panvinio's confrere Perini in a rather 'uncritical and erroneous' way. Here the reader is introduced to the different milieus in which Panvinio received his education and took his first steps: the cloisters of the Augustinian order, the influence of Girolamo Seripando, and finally, in Rome, the support of Alessandro Farnese.

In the papal Curia the Augustinian immediately gained financial and political support from several powerful figures. The histories of noble families that he wrote under commission in these first years show a certain proclivity to satisfy his patrons' desire for social aggrandizement, regardless of any other historical considerations. This methodological unscrupulousness is hardly a surprise: after all, as Bauer emphasizes, in the humanistic context of the time, forgeries were another method through which scholars could show their ability to imitate the ancients. In proposing these unbelievable genealogies, Panvinio revealed for the first time his ability as a historian, capable of combining antiquarian methods with historico-chronological notes that attest to a profound knowledge of the historical sources. Sophisticated philological skills and a critical analysis of original sources soon became the benchmark of Panvinio's works on Church history and Roman antiquities. When the Augustinian died in 1568, he was one of the most productive scholars on papal history that the Curia had known in many years. This production, ranging from the study of Roman republic to the constitutional history of the German Empire, came at a cost, however. In 1569, Pius V banned Panvinio's books, forbidding their publication. Bauer cannot find the motivations behind this surprising decision, but apparently, by using a refined source criticism, Panvinio was unveiling the weaknesses of the traditional accounts on papal history. Since then Panvinio's legacy remained primarily confined to a few connoisseurs, who had access to his handwritten works.

In Chapter 3 Bauer reduces the gaze of the analysis and examines one of Panvinio's learned treatises: the remarkable work De varia creatione Romani pontificis (I ed. 1559; II ed.: 1563), until today the first complete history of papal elections. A fine-grained investigation of the different versions of the book allows Bauer to draw from this work important conclusions on Panvinio's working method and on his understanding of the Papacy as a whole. In particular, the Appendix placed at the end of the volume provides an example of Panvinio's text-criticism: here the Augustinian discusses the authenticity of the well-known decree of 1059 on the papal election and searches for a solution through a detailed investigation of the sources.

It is worth noting that De varia creatione gives a view on the historical development of the papal office characterized more by change, diversity and chaos than by continuity and harmony. Panvinio in fact pinpoints eighteen different forms ('modes') of papal elections from St. Peter's times to the sixteenth century. The election with the exclusive participation of the cardinals represents the last mode, the one observed during Panvinio's lifetime — and which is still in use today. Within such 
a thorough examination, Panvinio does not show much interest in the origins and evolution of the complex ceremonial procedures practiced during the elections. He instead primarily aims to determine who exerted influence on the choice of Peter's successors throughout the long history of the Papacy. In describing the subsequent reforms of the papal elections, the Augustinian never casts doubt on the legitimacy of these regulations, which were always enforced and approved by the popes themselves. The goal of Panvinio's narrative is instead utterly 'political' and 'reformist': the De varia creatione at the very end shows that the Papacy took its historical shape thanks to an ongoing and legitimate process of reform.

Bauer convincingly explains the risks and consequences of such a narrative, which implicitly discriminated between the church as it should be and the church as it actually was. This approach was not devoid of dangers, as Roman censors immediately noted. Chapter 4 is devoted to highlighting the conflicts that historical writing provoked at a moment of particularly strong confessional tensions. In the eyes of Roman theologians, Panvinio's works, especially his Historia ecclesiastica and the continuation of Platina's prestigious Lives of Popes, appeared more harmful than helpful to the papal cause. After all, Panvinio's thorough research had led him to describe rather than to apologize unfortunate events of Church history. The De varia creatione similarly fell victim of such a meticulous (and unsympathetic) analysis of Panvinio's works. One of the most vocal critics of this book was the famous canonist Francisco Peña, whom Bauer identifies as one of the anonymous censors of Panvinio's work. Peña's severe reading of De varia creatione focuses on the political aspect of the treatise, which in his eyes seems much more attached to the Empire than to the Holy See.

In the epilogue, Bauer affirms that Panvinio wrote in an 'open and imaginative phase of history-writing' (212), in a transitional period between the late Renaissance and the age of Catholic Reform, when the confessionalization of ecclesiastical history had not taken place yet. Only from the 1580s, theological concerns started to dominate the historical discourse and to make Panvinio's works no longer viable for Catholic readers. As a result, Bauer's book not only offers the portrait of an outstanding historian but also sketches the profile of a whole epoch, during which historical writing took up new dimensions and challenges.

It remains highly problematic to decide whether Panvinio's works really 'invented' papal history. Bauer's book seems to suggest that the invention merely consisted in a deep change in methodology and narrative techniques. A few questions are however left open: which were the breaks and continuities with previous historiography? Was this new methodological consciousness really connected with a new understanding of Church history? In other words, in which form did Panvinio's work contribute to forging a new self-perception of the Papacy?

Despite the scholarly subject, the volume is highly readable and provides information to the less experienced reader (an example among many others from 
page 80: 'The Kalends were the first day of every month'). Furthermore, the book publishes a good selection of sources in translation, giving the original text in the footnotes. In addition to the extensive bibliography of archival and printed sources, a catalogue of Panvinio's works and the several versions printed and not would have also been beneficial. 